\title{
Prevalence and Virulence of Salmonella Bacteria Causing Salmonellosis in Post Weaning Pigs at Swine Farms in Bac Giang Province, Vietnam
}

\author{
Dang Xuan Binh ${ }^{1 *}$, Nghiem Ngoc Minh², Dao Thi Hoai Giang ${ }^{3}$ \\ ${ }^{1}$ Thai Nguyen University of Agriculture and Forestry \\ ${ }^{2}$ Institute of Genome Research, Vietnam Academy of Science and Technology \\ ${ }^{3}$ Sub Department of Animal Health in Lang Son
}

\begin{abstract}
Received: 14 November, 2017; Accepted: 18 November, 2017; Published: 23 November, 2017
*Corresponding author: Dang Xuan Binh, Thai Nguyen University of Agriculture and Forestry; Tel: +8484982970929; Email: binhdx@tnu.edu.vn
\end{abstract}

\section{Summary}

The release of Salmonella of 256 breeder sows from 20 swine farms in Hiep Hoa district, Bac Giang province, Viet Nam; The medical waste samples were collected in order to determine the prevalence, serotype and virulence of 166 Salmonellabacteria strains isolated from medical waste of post weaning pigs with Salmonellosis. It was found that:

Out of the 166 strains studied, the number of serotypes identified included 2 Salmonella weltevreden, 3 Salmonelladublin, 5 Salmonella anatumand Salmonella senftenberg, 6 Salmonella Heidelberg, 9 Salmonella enteritidis, 30 Salmonella typhimurium, 41 Salmonella choleraesuis, and 10 unknown Salmonella serotype.

Salmonella weltevreden which bore the encoded gene Stnac counted for $50.0 \%$; Salmonella dublinand Salmonella heidelberg accounted for $66.6 \%$; Salmonella typhimuriumaccounted for $73.3 \%$;Salmonella senftenberg, Salmonellaanatum,and Salmonella unknown accounted for $80.0 \%$; Salmonella enteritidisaccounted for88.8 \%; Salmonella choleraesuiscarrying the DNA bearing the gene producing Stnac counted for $92.6 \%$.

Salmonelladublinbearing the gene fim A accounted for 33.3 \%; Salmonella weltevreden accounted for 50.0 \%; Salmonella unknown accounted for $60.0 \%$; Salmonella typhimuriumand Salmonella heidelberg accounted for $66.6 \%$; Salmonella senftenberg and Salmonella anatum accounted for $80.0 \%$;Salmonella enteritidisaccounted for $88.8 \%$; and Salmonella choleraesuis accounted for $92.6 \%$.

Salmonella typhimurium bearing the gene InvA accounted for $26.6 \%$; Salmonella unknown accounted for $30.0 \%$;Salmonella heidelberg and Salmonella dublin accounted for 33.3 \%; Salmonella choleraesuis accounted for $39.0 \%$; Salmonella anatumand Salmonella senftenberg accounted for $40.0 \%$;Salmonella weltevreden accounted for $50.0 \%$; and Salmonella enteritidis accounted for $66.6 \%$.

Salmonella choleraesuis strains were resistant to nalidixic acid (2.4\%); ciprofloxacin, rifampicin, spectinomycin (7.3\%); ceftazidime, oxytetracycline (9.7\%); nitrofurantoin (12.1\%); trimethoprim-sulfamethoxazole (19.5\%); kanamycin (21.9\%).

Salmonella enteritidis strains were resistant to ciprofloxacin, rifampicin, ceftazidime, spectinomycin, nitrofurantoin (11.1\%); trimethoprimsulfamethoxazole, kanamycin (22.2\%).

Salmonella typhimurium strains were resistant to nitrofurantoin, nalidixic acid and ceftazidime (3.3\%); ciprofloxacin, spectinomycin and rifampicin (6.6\%); trimethoprim-sulfamethoxazole (16.6\%); kanamycin (20.0\%).

Keywords: Pig; Salmonella; Bacteria; Virulence

\section{Introduction}

Salmonella was first isolated from pigs by Salmon and Smith in 1886 [25]. The bacteria were found in the intestines of both warm and cold blood animals. With more than 2,400 serotypes, Salmonella has been identified as the cause for a number of diseases on human and animals. Having been identified for more than a hundred years, yet Salmonella is still the subject for numerous studies due to worldwide epiological problems on human and animals caused by the bacteria. It is estimated that every year, 155,000 people worldwide die of Salmonellosis and food poisoning [7, 8,9,10,19].
Of all the serotypes found, the ones which cause diseases on pigs are mainly Salmonella choleraesuis and Salmonella typhimurium. Salmonella derby, Salmonella Heidelberg, Salmonella Dublin and Salmonella enteritidis also cause diseases in pigs, with lower rates. Salmonella on pigs are found to cause diseases on pigs and food poisoning on human [14]. Pigs are the source of the diseases, bearing the bacteria and release highly virulent pathogens to the environment, causing diseases on cattles and poultry and diseases and food poisoning on human $[19,25]$. Food contaminated with Salmonella is the vector factor carrying pathogen, which causes food poisoning on human [33]. 


\section{Prevalence and Virulence of Salmonella Bacteria Causing Salmonellosis in Post Weaning Pigs at Swine Farms in Bac Giang Province, Vietnam}

In December 2016, in Hiep Hoa district, Bac Giang, there were 97 swine farms and more than 220 small family farms for cattles and poultry. Of which, there were 25 swine farms with at least 50 sows for breeding and 150 small family farms with at least 100 market pigs (for meat). A number of families raising thousands of poultry for eggs or meat.

This study focus on identifying the prevalence of Salmonella on sows and post weaning pigs (healthy pigs and pigs with diarrhea), enriching scientific materials on the prevalence of the disease (etiology), which may lead to new studies on diagnosis and effective control methods for the prevalence and release of Salmonellawhich causes diseases on animals and food poisoning on human.

\section{Materials and Methods}

The study objectives were to investigate Salmonella prevalence; serotyping and virulence factors distribution of 256 breeder sows from 20 swine farms in Hiep Hoa district, Bac Giang province, Viet Nam; the disease samples from the post weaning Salmonellosis pigs were collected and cultured for Salmonella role; serotyping and virulence of 166 Salmonella bacteria strains isolates from disease samples of the post weaning diarrhea pigs was determined. Approximately, a total of 210 disease samples of post weaning Salmonellosis pigs will be collected from the swine farms. The samples were collected in sterilized polyethylene bags and transported to the Institute of Life Science, Thai Nguyen Agriculture and Forestry Universityin an icebox for further processing and microbiological analysis. All the samples collected are shown in Table 8.

Collect faces samples to determine number of bacteria; collect medical waste for isolation; examine biological and chemical characteristics; determine virulence, test for antibiotic and pharmachemical resistance of Salmonella according to Quinn P.J et al.; Wallace H. Andrews, et al. [21,30]. Bacteriological Analytical Manual (Chapter 5,Salmonella).

Examine serotype Salmonella isolates using Test Kit O antigens, $\mathrm{H}$ (antigens phase 1, antigens phase 2) of Bio-Rad (Bacterial serotyping guide for Salmonella); Oxoid SalmonellaTest Kit.

Antibiotic susceptibility testing was performed by the KirbyBauer disc-diffusion test, which conforms to the recommended standard as described by [21]. Briefly, an inoculum of each pure bacterial isolate was emulsified in $3 \mathrm{~mL}$ of sterile normal saline and the density adjusted to 0.5 McFarland standard A sterile cotton swab was dipped into the standardized suspension of bacterial cultures and used to inoculate MuellerHinton agar (MHA) plates (Oxoid, England), and the plates were allowed to dry. Antibiotic discs with the following drug contents amoxicilline, nitrofurantoin, ciprofloxacin, bacitracin, erythromycin, oxytetracycline, ceftazidime, nalidixic acid gentamycin, vancomycin, oxacillin, kanamycin, and rifampicin, (Antibiotic Becton, Dickson and Company, Sparks, USA; Le Pont de Claix, France) were placed onto MHA plates. The plates were incubated at $37^{\circ} \mathrm{C}$ for 24 hours. The zone diameter was measured and results were interpreted based on Quinn PJ, et al. [21]. The reference strains Salmonellawere used to verify the quality and accuracy of the testing procedure.

Multiplex polymerase chain reaction analysis of the targeted genes of interest was performed using DreamTaq DNA polymerase (Thermo Scientific, USA). For the amplification, five microlitres of DNA was added to $20 \mu \mathrm{L}$ of master mix containing $12.5 \mu \mathrm{L}$ of DreamTaq DNA polymerase (2X DreamTaq Green Buffer, dATP, dCTP, dGTP, and dTTP, $0.4 \mathrm{mM}$ each, and $4 \mathrm{mM} \mathrm{MgCl}_{2}$ ) (Thermo Scientific, USA), $0.5 \mu \mathrm{L}(0.2 \mu \mathrm{M})$ of respective oligonucleotide primers and the reaction volume was made up with nuclease free water. PCR was performed in a thermal cycler (Bio-Rad Laboratories, USA). The amplification cycles consisted of an initial DNA denaturation at $95^{\circ} \mathrm{C}$ for $15 \mathrm{~min}$, followed by 35 cycles of denaturation at $94^{\circ} \mathrm{C}$ for $45 \mathrm{~s}$, primer annealing at $55^{\circ} \mathrm{C}$, for $45 \mathrm{~s}$, extension at $68^{\circ} \mathrm{C}$ for $2 \mathrm{~min}$, and a final single elongation at $72^{\circ} \mathrm{C}$ for $5 \mathrm{~min}$. The primers used to amplify the targeted genes were as previously reported by Institute of Genome Research, Vietnam Academy of Science and Technology and are summarized in Table 1. Negative controls, substituting DNA template with ultrapure water (Sigma-Aldrich, UK), were included in all PCR runs. Amplified DNA was resolved by $2 \%$ agarose gel electrophoresis and visualised under UV transillumination

Biological statistic was processed with SPSS: Statistical analysis was performed using SPSS version 22.0. The chi-square test was used to compare rate of isolation of the various disease samples and the different study sites. Comparisons were also done among the farms. Differences were considered significant at $\mathrm{P}<0.05$.

\begin{tabular}{|c|c|c|c|c|}
\hline $\begin{array}{l}\text { Primer } \\
\text { pair } \\
\text { target }\end{array}$ & $\begin{array}{l}\text { Primer sequence } \\
\qquad\left(5^{\prime} \rightarrow 3^{\prime}\right)\end{array}$ & $\begin{array}{l}\text { Annealing } \\
\text { temp }\left({ }^{\circ} \mathrm{C}\right)\end{array}$ & $\begin{array}{c}\text { Length } \\
\text { (bp) }\end{array}$ & Reference \\
\hline invA & $\begin{array}{c}\text { F: GTG AAA TTA } \\
\text { TCG CCA CGT TCG } \\
\text { GGC AA } \\
\text { R: TCA TCG CAC CGT } \\
\text { CAA AGG AAC C }\end{array}$ & 63 & 521 & [12] \\
\hline stn & $\begin{array}{c}\text { F: CTT TGG TCG TAA } \\
\text { AAT AAG GCG } \\
\text { R: TGC CCA AAG } \\
\text { CAG AGA GAT TC }\end{array}$ & 55 & 260 & [15] \\
\hline fimA & $\begin{array}{c}\text { F: CCT TTC TCC ATC } \\
\text { GTC CTG AA } \\
\text { R: TGG TGT TAT } \\
\text { CTG CCT GAC CA }\end{array}$ & 56 & 85 & [16] \\
\hline
\end{tabular}

\section{Results and Discussion}

\section{Release of Salmonella in sows and young pigs}

\section{Release of Salmonella in Sows}

Faces samples from 265 sows in 20 swine farms in eight communes and one district town in Hiep Hoa district, Bac Giang province were collected to determine the prevalence and release of Salmonella. The results are presented in Table 2. 
Prevalence and Virulence of Salmonella Bacteria Causing Salmonellosis in Post Weaning Pigs at Swine Farms in Bac Giang Province, Vietnam

Table 2: Release of Salmonellain sows by place and individual

\begin{tabular}{|c|c|c|c|c|c|c|}
\hline \multirow[t]{2}{*}{ Research site } & \multicolumn{3}{|c|}{ Release of Salmonella by place } & \multicolumn{3}{|c|}{ Release of Salmonella by individual } \\
\hline & No. of farms studied & $\begin{array}{c}\text { No. of farms with } \\
\text { sowsreleasing of Salmonella }\end{array}$ & Rate & No. of sows studied & $\begin{array}{c}\text { No. of sowsreleasing of } \\
\text { Salmonella }\end{array}$ & Rate \\
\hline TT Thang & 2 & 2 & 100 & 31 & 12 & 38.7 \\
\hline Duc Thang & 3 & 3 & 100 & 33 & 9 & 27.2 \\
\hline Ngoc Son & 3 & 3 & 100 & 39 & 15 & 38.4 \\
\hline Danh Thang & 2 & 2 & 100 & 30 & 11 & 36.6 \\
\hline Bac Ly & 3 & 3 & 100 & 30 & 13 & 43.3 \\
\hline Dong Lo & 2 & 2 & 100 & 32 & 12 & 37.5 \\
\hline Luong Phong & 2 & 2 & 100 & 36 & 10 & 27.7 \\
\hline Mai Trung & 3 & 3 & 100 & 34 & 9 & 26.4 \\
\hline Total & 20 & 20 & 100 & 265 & 91 & 34.3 \\
\hline
\end{tabular}

From Table 2, it can be seen that: The release of Salmonella occurred in all the sow farms (accounting for100\%). The highest rate of Salmonella release was $26.4 \%$ (Mai Trung), and the lowest rate was $43.3 \%$ (Bac Ly). The average rate of Salmonella release from sows to the farm environment was $34.3 \%$.With $\mathrm{P}>0.05$ it can be said that the difference on the rates of Salmonella release from sows between the farms are not significant. The results were totally in line with those of Lo FO Wong, et al. on release of Salmonella from pigs [14]. In an earlier study, Jerome C. Nietfeld, et al. also found the rate of Salmonella isolates from pig rectal swabs was $46.6 \%$

\section{Release of Salmonella in Sows by Parity}

Faces samples were collected from 240 local breeder sows in Hiep Hoa district, Bac Giang by parities at different time frames in order to determine the level of Salmonella release. The results are presented in Table 3.

Table 3: Release of Salmonellain sows by parity

\begin{tabular}{|c|c|c|c|c|c|c|c|c|c|c|}
\hline \multirow{2}{*}{$\begin{array}{l}\text { Sample collection } \\
\text { time }\end{array}$} & \multicolumn{3}{|c|}{ Parity 1 sows (Primiparous) } & \multicolumn{3}{|c|}{ Sows in parities 2-5 (Pluriparous) } & \multicolumn{3}{|c|}{$\begin{array}{l}\text { Higher than } 5 \text { parities sows } \\
\text { (Aged sows) }\end{array}$} & \multirow[t]{2}{*}{ Total } \\
\hline & $\begin{array}{l}\text { No. of } \\
\text { sows } \\
\text { studied }\end{array}$ & $\begin{array}{l}\text { No. of sows } \\
\text { realeasing } \\
\text { bacteria }\end{array}$ & $\begin{array}{l}\text { Rate } \\
(\%)\end{array}$ & $\begin{array}{l}\text { No. of } \\
\text { sows } \\
\text { studied }\end{array}$ & $\begin{array}{l}\text { No. of sows } \\
\text { realeasing } \\
\text { bacteria }\end{array}$ & Rate $(\%)$ & $\begin{array}{l}\text { No. of } \\
\text { sows } \\
\text { studied }\end{array}$ & $\begin{array}{l}\text { No. of sows } \\
\text { realeasing } \\
\text { bacteria }\end{array}$ & $\begin{array}{l}\text { Rate } \\
(\%)\end{array}$ & \\
\hline $\begin{array}{c}\text { One week after } \\
\text { farrowing ( } 7 \text { to } 14 \\
\text { days) }\end{array}$ & 13 & 5 & 38.4 & 31 & 16 & 51.6 & 25 & 5 & 20 & $\begin{array}{c}26 / 69 \\
(37.6 \%)\end{array}$ \\
\hline $\begin{array}{c}\text { Two weeks after } \\
\text { farrowing (14 to } 21 \\
\text { days) }\end{array}$ & 11 & 2 & 18.1 & 29 & 18 & 62 & 22 & 5 & 22.7 & $\begin{array}{c}25 / 62 \\
(40.3 \%)\end{array}$ \\
\hline $\begin{array}{c}\text { One week after } \\
\text { weaning ( } 21 \text { to } 28 \\
\text { days) }\end{array}$ & 14 & 2 & 14.2 & 35 & 12 & 34.2 & 21 & 5 & 23.8 & $\begin{array}{c}19 / 70 \\
(27.1 \%)\end{array}$ \\
\hline
\end{tabular}

Table 3 shows that Release of Salmonellain sows according to the stages of two weeks before farrowing, one week after farrowing, (piglets of 14 to 21 days), one week after weaning (piglets of 21 to 28 days). The details are as follows:

Two weeks before farrowing, the release of Salmonella was 25.0 \%in one-parity sows; $50.0 \%$ in sows in parities 2-5; and 16.6 $\%$ in higher-than-five-parity sows (In total in one week before farrowing sows the release of Salmonella accounted for32.8\%).
One week after farrowing, the release of Salmonella was $38.4 \%$ in one-parity sows; 51.6 \%in sows in parities 2-5; 20.0 $\%$ in higher-than-five-parity sows (In total, in one week after farrowing sows the release of Salmonella accounted for $37.6 \%$ ).

Two weeks after farrowing, the release of Salmonella was18.1\%in one-parity sows; $62.0 \%$ in sows in parities $2-5 ; 22.7$ \%in higher-than-five-parity sows(In total, in two weeks after farrowing sows, the release of Salmonella accounted for $40.3 \%$ ). 


\section{Salmonellosis in Post Weaning Pigs at Swine Farms in Bac Giang Province, Vietnam}

One week after weaning, the release of Salmonella was 14,2 $\%$ in one-parity sows; $34.2 \%$ in sows in parities $2-5 ; 23.8 \%$ in higher-than-five-parity sows(In total, in one week after weaning sows, the release of Salmonella accounted for27.1\%).

With $\mathrm{P}<0.05$, it can be said that the differences between the stages of sows in the rates of Salmonella release are statistically significant. The results are similar to those of Tran TP, et al. on the release of Salmonella from pigs, chicken and ducks in a study in Mekong delta, Vietnam; and Chiara F. Magistrali et al., 2011 on the release of Salmonella from groups of sows in Italy, which showed that Salmonella release accounted for $33.3 \%$ of one-parity sows(in primiparous), $28.8 \%$ of sows in parities $2-5$ (in pluriparous), and $4.6 \%$ of higher-than-five-parity sows(aged sows) [5,27].

\section{Release of Salmonellain Sows by Season}

Due to the climate characteristics of Hiep Hoa district, Bac Giang, which belongs to northern mountaineous region of Vietnam, with four distinct seasons, faces samples were collected from sows in eight communes and district towns, including Thang district town (T) and the communes of Duc Thang (DT), Ngoc Son (NS), Danh Thang (DT), Bac Ly (BL), Dong Lo (DL), Luong Phong (LP) and Mai Trung (MT) in order to determine the release of Salmonella by season. The results are presented in Table 4 .

\begin{tabular}{|c|c|c|c|c|c|c|c|c|c|c|c|c|}
\hline \multirow{3}{*}{$\begin{array}{l}\text { Study } \\
\text { site }\end{array}$} & \multirow{2}{*}{\multicolumn{3}{|c|}{$\begin{array}{c}\text { Spring } \\
\text { (Feb-Apr) }\end{array}$}} & \multirow{2}{*}{\multicolumn{3}{|c|}{$\begin{array}{l}\text { Summer } \\
\text { (May-Jul) }\end{array}$}} & \multirow{2}{*}{\multicolumn{3}{|c|}{$\begin{array}{c}\text { Thu } \\
\text { (Aug-Oct) }\end{array}$}} & \multirow{2}{*}{\multicolumn{2}{|c|}{$\begin{array}{c}\text { Winter } \\
\text { (Nov-Jan) }\end{array}$}} & \multirow[b]{3}{*}{$\begin{array}{l}\text { Rate } \\
(\%)\end{array}$} \\
\hline & & & & & & & & & & & & \\
\hline & $\begin{array}{c}\text { Sows } \\
\text { examined }\end{array}$ & $\begin{array}{l}\text { Sows } \\
\text { releasing } \\
\text { the } \\
\text { bacteria }\end{array}$ & $\begin{array}{l}\text { Rate } \\
(\%)\end{array}$ & $\begin{array}{c}\text { Sows } \\
\text { examined }\end{array}$ & $\begin{array}{l}\text { Sows } \\
\text { releasing } \\
\text { the } \\
\text { bacteria }\end{array}$ & $\begin{array}{l}\text { Rate } \\
(\%)\end{array}$ & $\begin{array}{c}\text { Sows } \\
\text { examined }\end{array}$ & $\begin{array}{l}\text { Sows } \\
\text { releasing } \\
\text { the } \\
\text { bacteria }\end{array}$ & $\begin{array}{l}\text { Rate } \\
(\%)\end{array}$ & $\begin{array}{c}\text { Sows } \\
\text { examined }\end{array}$ & $\begin{array}{l}\text { Sows } \\
\text { releasing } \\
\text { the } \\
\text { bacteria }\end{array}$ & \\
\hline $\mathrm{T}$ & 8 & 5 & 62.5 & 6 & 3 & 50 & 9 & 3 & 33.3 & 8 & 1 & 12.5 \\
\hline DT & 9 & 4 & 44.4 & 9 & 3 & 33.3 & 8 & 2 & 25 & 7 & 0 & 0 \\
\hline NS & 11 & 6 & 54.5 & 9 & 4 & 44.4 & 10 & 4 & 40 & 9 & 1 & 11.1 \\
\hline DT & 8 & 5 & 62.5 & 6 & 2 & 33.3 & 8 & 2 & 25 & 8 & 2 & 25 \\
\hline BL & 7 & 5 & 71.4 & 7 & 4 & 57.1 & 8 & 3 & 37.5 & 8 & 1 & 12.5 \\
\hline DL & 8 & 5 & 62.5 & 6 & 3 & 50 & 9 & 2 & 22.2 & 9 & 2 & 22.2 \\
\hline LP & 10 & 4 & 40 & 9 & 3 & 33.3 & 8 & 2 & 25 & 9 & 1 & 11.1 \\
\hline MT & 8 & 3 & 37.5 & 8 & 3 & 37.5 & 9 & 3 & 33.3 & 9 & 0 & 0 \\
\hline
\end{tabular}

Table 4 shows that there were differences in the release of Salmonellain sowsby seasons: spring (Feb-Apr); summer (MayJul); autumn (Aug-Oct); winter (Nov-Jan) with higher rates in spring and summer, and lower rates in autumn and winter. The details are as follows:

In spring, the release of Salmonella from sows waslo west with $37.5 \%$ (MT), and the highest rate was $71.4 \%$ (BL); in summer, the release of Salmonella showed some signs of decreasing yet not clear $(\mathrm{P}>0.05)$, The lowest release rate was $33.3 \%$ (LP, DT, DT), and the highest rate was $57.1 \%$ (BL); autumn rate of release of Salmonellain sows decreased remarkably $(\mathrm{P}<0.05)$, The lowest rate of release was $22.5 \%$ (DL), the highest rate of release was $40.0 \%$ (NS); in winter Release of Salmonella continued to decrease, similarly, autumn $(\mathrm{P}<0.05)$, The lowest rate of release was $0 \%$ (MT, DT), the highest rate of release was $25.0 \%$ (DT).

The results were in line with those of Wendy Wilkins, et al. in Alberta and Saskatchewan, Canada on pig samples found positive with Salmonella: the ones found positive with Salmonella accounted for $36 \%$, of which Salmonella isolates from sows accounted for $43 \%$, from weaners accounted for $29 \%$; in finishing pigs, the rate of Salmonella release accounted for $28 \%$; the rates of Salmonella isolated from farm environment ranged from $1 \%$ to $79 \%$ [32].

\section{Release of Salmonella in Small Pigs}

Faces samples were collected from post weaning pigs to determine the release of Salmonella in the faces before and after diarrhea suspected of contracting Salmonellosis. The results are presented in Table 5.

Table 5 shows that there are significant differences $(\mathrm{P}<0.05)$ in the release of Salmonella in healthy pigs and pigs with diarrhea suspected of contracting Salmonellosisin both before and after weaning. The details are as follows:

Before weaning (7 to 14 days): The lowest rate of release of Salmonellain healthy pigs (with no symptom of diarrhea) were from $2.0 \%$ (LP) to the highest rate of $3.9 \%$ (DT). Three communes were found with no positive sample to Salmonella (MT, NS and DL). The total rate of release of Salmonella in healthy pigs in this stage was $6 / 357$, accounting for $1.68 \%$; The lowest rate of positive samples to Salmonella in pigs with diarrhea was from $25.0 \%$ (Pigs with diarrhea in DL) to $33.3 \%$ (Pigs with diarrhea in DT), Pigs with diarrhea in the remaining communes were found negative to Salmonella (MT, LP, BL, DT, NS, T). The total rate of release of Salmonella in this stage in pigs with diarrhea was $2 / 22$, accounting for $9.0 \%$. The isolation of Salmonella from pigs with diarrhea symptoms in this stage was in line with the 
Prevalence and Virulence of Salmonella Bacteria Causing Salmonellosis in Post Weaning Pigs at Swine Farms in Bac Giang Province, Vietnam

\begin{tabular}{|c|c|c|c|c|c|c|c|c|c|c|c|c|}
\hline \multirow{3}{*}{$\begin{array}{l}\text { Study } \\
\text { site }\end{array}$} & \multicolumn{6}{|c|}{ Before weaning (7-14 days) } & \multicolumn{6}{|c|}{ After weaning (21-35 days) } \\
\hline & \multicolumn{3}{|c|}{ Healthy pigs } & \multicolumn{3}{|c|}{ Pigs with diarrhea } & \multicolumn{3}{|c|}{ Healthy pigs } & \multicolumn{3}{|c|}{ Pigs with diarrhea } \\
\hline & $\begin{array}{c}\text { Sows } \\
\text { examined }\end{array}$ & $\begin{array}{l}\text { Sows } \\
\text { releasing } \\
\text { the } \\
\text { bacteria }\end{array}$ & $\begin{array}{l}\text { Rate } \\
(\%)\end{array}$ & $\begin{array}{c}\text { Sows } \\
\text { examined }\end{array}$ & $\begin{array}{l}\text { Sows } \\
\text { releasing } \\
\text { the bacteria }\end{array}$ & $\begin{array}{l}\text { Rate } \\
(\%)\end{array}$ & $\begin{array}{c}\text { Sows } \\
\text { examined }\end{array}$ & $\begin{array}{l}\text { Sows } \\
\text { releasing } \\
\text { the } \\
\text { bacteria }\end{array}$ & $\begin{array}{l}\text { Rate } \\
(\%)\end{array}$ & $\begin{array}{c}\text { Sows } \\
\text { examined }\end{array}$ & $\begin{array}{l}\text { Sows } \\
\text { releasing } \\
\text { the } \\
\text { bacteria }\end{array}$ & $\begin{array}{l}\text { Rate } \\
(\%)\end{array}$ \\
\hline $\mathrm{T}$ & 42 & 1 & 2.3 & 2 & 0 & 0 & 42 & 5 & 11.9 & 3 & 3 & 100 \\
\hline DT & 51 & 2 & 3.9 & 3 & 1 & 33.3 & 51 & 3 & 5.8 & 3 & 3 & 100 \\
\hline NS & 39 & 0 & 0 & 2 & 0 & 0 & 39 & 4 & 10.2 & 2 & 2 & 100 \\
\hline DT & 36 & 1 & 2.7 & 3 & 0 & 0 & 36 & 5 & 13.8 & 4 & 4 & 100 \\
\hline BL & 44 & 1 & 2.2 & 3 & 0 & 0 & 44 & 4 & 9 & 3 & 3 & 100 \\
\hline LP & 50 & 1 & 2 & 2 & 0 & 0 & 50 & 6 & 12 & 3 & 3 & 100 \\
\hline MT & 46 & 0 & 0 & 3 & 0 & 0 & 46 & 5 & 10.8 & 3 & 3 & 100 \\
\hline
\end{tabular}

characteristics of Salmonellosis in pigs, which usually only occur in post weaning pigs, and with the characteristics of Colibacillosis in pigs before weaning, which are usually caused by E. coli $[11,25]$.

Post weaning pigs (21 to 35 days): the lowest rate of release of Salmonella in healthy pigs was $5.8 \%$ (DT), and the highest rate was $13.8 \%$ (DT). The total rate of release of Salmonella in healthy pigs in this stage was $36 / 357$, accounting for $10.0 \%$; the rate of release of Salmonella in small pigs with diarrhea was $100 \%$. Thus, the results were in line with those of Wendy Wilkins, et al.; Tran TP, et al.; Chiara F. Magistrali, et al.; and Pires AF, et al.; Li Bai, et al. on the release of Salmonella from pigs in several farms all over the world [5,12,13,20,27,32].

\section{Differences in the Total Count of Salmonella released in The Faces in Post Weaning Pigs}

Table 5 shows that face samples were collected from post weaning pigs, both healthy ones and ones with diarrhea due to Salmonellosis to determine the differences in the total count of Salmonella pathogens released in one gram of faces. This is to determine the total count of Salmonella released and to determine the role of Salmonella in the causing Salmonellosisin post weaning pigs in Hiep Hoa district, Bac Giang province. The results are presented in Table 6.

Table 6: The differences in total count of Salmonella released from post weaning pigs

\begin{tabular}{|c|c|c|c|c|c|c|}
\hline \multirow[b]{2}{*}{ Study site } & \multicolumn{3}{|c|}{ Healthy pigs } & \multicolumn{3}{|c|}{ Pigs with diarrhea (Salmonellosis) } \\
\hline & $\begin{array}{c}\text { Samples } \\
\text { examined }\end{array}$ & Positive samples & $\begin{array}{l}\text { Salmonella in } 1 \mathrm{gr} \text { of } \\
\text { faces }\end{array}$ & $\begin{array}{c}\text { Samples } \\
\text { examined }\end{array}$ & Positive samples & $\begin{array}{l}\text { Salmonella in } 1 \mathrm{gr} \text { of } \\
\text { faces }\end{array}$ \\
\hline $\mathrm{T}$ & 42 & 5 & $0.32 \times 10^{6}$ & 3 & 3 & $0.65 \times 10^{9}$ \\
\hline DT & 51 & 3 & $0.93 \times 1^{06}$ & 3 & 3 & $0.29 \times 10^{9}$ \\
\hline NS & 39 & 4 & $0.28 \times 10^{6}$ & 2 & 2 & $0.34 \times 10^{9}$ \\
\hline DT & 36 & 5 & $0.51 \times 10^{6}$ & 4 & 4 & $0.46 \times 10^{9}$ \\
\hline BL & 44 & 4 & $0.83 \times 10^{6}$ & 3 & 3 & $0.18 \times 10^{9}$ \\
\hline DL & 49 & 4 & $0.68 \times 10^{6}$ & 4 & 4 & $0.23 \times 10^{9}$ \\
\hline LP & 50 & 6 & $0.39 \times 10^{6}$ & 3 & 3 & $0.56 \times 10^{9}$ \\
\hline MT & 46 & 5 & $0.62 \times 10^{6}$ & 3 & 3 & $0.75 \times 10^{9}$ \\
\hline
\end{tabular}

Table 6 shows that: The number of Salmonella released from pigs with Salmonellosis was from $0.18 \times 109 \mathrm{CFU} /$ Gram of faces to $0.75 \times 109 \mathrm{CFU} / \mathrm{Gram}$ of faces, higher than the number of Salmonella released from healthy pigs, which was from 0.28 x $106 \mathrm{CFU} /$ Gram of faces to $0.93 \times 106 \mathrm{CFU} /$ Gram of faces $(\mathrm{P}<$ 0.05). Thus, the number of Salmonella released from pigs with diarrhea was higher than that from healthy pigs(from $0.28 \mathrm{x}$ $106 \mathrm{CFU} / \mathrm{Gr}$ to $0.93 \times 106$ ) and pigs with diarrhea(from 0.23 $\mathrm{x} 109 \mathrm{CFU} / \mathrm{Gr}$ to $0.75 \mathrm{x} 109 \mathrm{CFU} / \mathrm{Gr}$ ), which was similar to the results of the experiment by Nicole C. Burdick Sanchez et al., 2017 on determining the release of Salmonella in the faces $24 \mathrm{~h}, 48 \mathrm{~h}$, and $72 \mathrm{~h}$ after the pigs were infected with Salmonella (from 3.9 x $109 \mathrm{CFU} /$ Grto $4.1 \times 109 \mathrm{CFU} / \mathrm{Gr}$ ), and similar to the results by Pires AF, et al., 2013 on the release of Salmonella in finishing pigs $[17,20]$.

In addition, it can be seen that the numbers of Salmonella released in the faces of post weaning pigs with diarrhea in our research are nearly similar to those used for infecting post 
weaning pigs of Walsh. MC , et al.;Nicole C. Burdick Sanchez, et al. when post weaning pigs were infected by drinking soups with the bacteria with the doses of $1010 \mathrm{CFU} /$ pig and 4.7x109 CFU/pig with the strain of Salmonella typhimurium $[17,31]$

\section{Prevalence of Salmonellosisin post weaning pigs}

\section{Epidemic Characteristics of Salmonellosis in Post Weaning Pigs}

A survey was conducted to determine the prevalence of
Salmonellosisin pigs from post weaning (21 days) to finishing (4 months) stages. The results are presented in Table 7. From Table 7, it can be seen that post weaning pigs with Salmonellosis accounting for from $5.1 \%$ (Ngoc Son) to11.1 \%(Danh Thang); Mortality rate were from 25.0 \%(Danh Thang) to $33.3 \%$ (Luong Phong and Thang district town), in other communes (Duc Thang, Ngoc Son, Bac Ly, Dong Lo, Mai Trung) the mortality rate of pigs with Salmonellosis was 0\%. The results were similar to those of Steven A. Carlson, et al. on diseases caused by Salmonella on post weaning pigs [25].

Table 7: Prevalence of Salmonellosis in post weaning pigs

\begin{tabular}{|c|c|c|c|c|}
\hline Study site & $\begin{array}{c}\text { No. of pigs } \\
\text { studied }\end{array}$ & No. of pigs with Salmonellosis & $\begin{array}{c}\text { Rate of pigs with } \\
\text { Salmonellosis (\%) }\end{array}$ & No. of dead pigs \\
\hline TT Thang & 42 & 3 & 7.1 & 1 \\
\hline Duc Thang & 51 & 3 & 5.8 & 0 \\
\hline Ngoc Son & 39 & 2 & 5.1 & 0 \\
\hline Danh Thang & 36 & 4 & 11.1 & 0 \\
\hline Bac Ly & 44 & 3 & 6.8 & 0 \\
\hline Dong Lo & 49 & 4 & 8.1 & 0 \\
\hline Luong Phong & 50 & 3 & 6 & 0 \\
\hline Mai Trung & 46 & 3 & 6.5 & 0 \\
\hline
\end{tabular}

Isolation of Salmonella from Medical Waste of Post Weaning Pigs with Diarrhea

Medical waste samples were collected from post weaning pigs with Salmonellosis (liver, kidney, heart blood, intestine nodes, small and large intestine fluid, with 30 samples each) to isolate Salmonella. The results are presented in Table 8.

Table 8 : Isolation of Salmonella from medical waste of post weaning pigs with Salmonellosis

\begin{tabular}{|c|c|c|c|}
\hline Types of sample & Number & $\begin{array}{c}\text { No. of } \\
\text { positive } \\
\text { samples }\end{array}$ & Rate (\%) \\
\hline Liver & 30 & 16 & 53.3 \\
\hline Kidney & 30 & 18 & 60 \\
\hline Heart blood & 30 & 22 & 73.3 \\
\hline Intestine nodes & 30 & 20 & 66.6 \\
\hline Small intestine fluid & 30 & 30 & 100 \\
\hline Large intestine fluid & 30 & 30 & 100 \\
\hline Diarrhea faces & 30 & 30 & 100 \\
\hline Total & $\mathbf{2 1 0}$ & $\mathbf{1 6 6}$ & $\mathbf{7 9}$ \\
\hline
\end{tabular}

Table 8 shows that the rate of Salmonella isolated was from $53.3 \%$ (liver samples) to $60.0 \%$ (kidney samples), $66.6 \%$ (intestine nodes), and $73.3 \%$ (heart blood samples). From the samples of small and large intestines, and diarrhea faces, the rate of Salmonella isolates was $100 \%$. Similar to Table 6, the results were similar to those of Steven A. Carlson, et al. on infection ability of Salmonella, and of Nicole C. Burdick Sanchez, et al. on the rate of Salmonella isolates in medical waste samples of liver, spleen, kidney, large intestine, intestine nodes, and faces after the pigs were infected with the disease $[16,17,18,25]$.

\section{Testing for Biological and Chemical Characteristics of Salmonella Isolates}

A test for biological and chemical characteristics was performed on the Salmonella strains isolated (91 strains). The results are presented in Table 9.

Table9: Biological and chemical characteristicsof Salmonella isolates

\begin{tabular}{|c|c|c|c|}
\hline \multirow{2}{*}{$\begin{array}{c}\text { Tests onBiological and } \\
\text { chemical characteristics }\end{array}$} & \multicolumn{3}{|c|}{ Results } \\
\cline { 2 - 4 } & $\begin{array}{c}\text { No. of strains } \\
\text { tested }\end{array}$ & Positive & Rate (\%) \\
\hline $\begin{array}{c}\text { Grow and multiply } \\
\text { inRappaport-Vassiliadis } \\
\text { environment at 42oC }\end{array}$ & 166 & 166 & 100 \\
\hline Gram negative stain & 166 & 166 & 100 \\
\hline Mobility & 166 & 58 & 34.9 \\
\hline Hemolysis on blood agar & 166 & 0 & 0 \\
\hline Lactose fermentation & 166 & 0 & 0 \\
\hline Production of $\mathrm{H}_{2} \mathrm{~S}$ & 166 & 166 & 100 \\
\hline
\end{tabular}

Table 9 shows that Salmonella isolates processed typical biological and chemical characteristics of the genus; $100 \%$ of the strains isolated grew and multiply well in Rappaport-Vassiliadis environment at $42^{\circ} \mathrm{c}$; Gram-negative stain (stained of safranin red of Gram dye); $34.9 \%$ have mobility; did not cause hemolysis in blood agar environment; there were no lactose fermentation; 
$100 \%$ of the strains tested produced $\mathrm{H}_{2} \mathrm{~S}$. The results were in line with those of Quinn P J, et al.; Steven A. Carlson, et al. on biological characteristics of Salmonella causing disease on pigs and food poisoning on human $[21,22,23,24,25]$.

\section{Virulence of Salmonella Isolates}

Virulence of Salmonella isolates was tested on healthy tested mice (Specific Pathogen Free). The results are presented in Table10.

\begin{tabular}{|c|c|c|c|c|c|c|c|c|c|}
\hline \multirow{2}{*}{ Sources } & \multirow{2}{*}{ Strains } & \multirow{2}{*}{ Mice tested } & \multirow{2}{*}{$\begin{array}{c}\begin{array}{c}\text { Dose of } \\
\text { abnormal } \\
\text { injection }\end{array} \\
\text { (ml/mouse) }\end{array}$} & \multicolumn{5}{|c|}{ No. of dead mice after infection (a) } & \multirow{2}{*}{$\begin{array}{c}\text { Dead rate } \\
(\%)\end{array}$} \\
\hline & & & & 8 hours & 24 hours & 32 hours & 48 hours & 6 days & \\
\hline Liver & 16 & 32 & 0.2 & 18 & 23 & 32 & & 32 & 100 \\
\hline Kidney & 18 & 36 & 0.2 & 12 & 26 & 36 & & 36 & 100 \\
\hline Heart blood & 22 & 44 & 0.2 & 19 & 28 & 35 & 43 & 43 & 97.7 \\
\hline Intestine nodes & 20 & 40 & 0.2 & 19 & 28 & 40 & & 40 & 100 \\
\hline $\begin{array}{l}\text { Small intestine } \\
\text { fluid }\end{array}$ & 30 & 60 & 0.2 & 36 & 48 & 55 & 56 & 56 & 93.3 \\
\hline $\begin{array}{l}\text { Large intestine } \\
\text { fluid }\end{array}$ & 30 & 60 & 0.2 & 34 & 43 & 51 & 53 & 53 & 88.3 \\
\hline Diarhea faces & 30 & 60 & 0.2 & 38 & 53 & 56 & 51 & 51 & 85 \\
\hline
\end{tabular}

From Table 10, it can be seen that Salmonella isolates were highly virulent on tested mice. Sau 48 hours after being infected with the bacteria, the tested mice died of the strains isolated from diarrhea faces; large intestine fluid, small intestine fluid, heart blood, and from intestine nodes, kidney and liver were $85.0 \%$, $88.3 \%, 93.3 \%, 97.7 \%$, and $100 \%$ respectively. From the dead mice, Salmonella was again isolated from the similar sources of Determination of the serotypes of Salmonella isolates

Determination of the serotypes of 166 Salmonella strain isolates was performed with quick agglutination reactionon glass slides using $\mathrm{O}, \mathrm{H}$ antigen kit $(\mathrm{H}$ anstigens phase $1, \mathrm{H}$ anstigens phase 2) from Bio-Rad Laboratories, Inc. The results are presented in Table11.

Table 11: Serotype of Salmonella isolates from medical waste of pigs with Salmonellosis

\begin{tabular}{|c|c|c|c|c|c|c|c|c|}
\hline \multirow[b]{2}{*}{ Serotype } & \multicolumn{7}{|c|}{ Sources of Salmonellaisolation } & \multirow[b]{2}{*}{ Total } \\
\hline & Liver & Kidney & $\begin{array}{l}\text { Heart } \\
\text { blood }\end{array}$ & Intestine nodes & $\begin{array}{l}\text { Small intestine } \\
\text { fluid }\end{array}$ & $\begin{array}{l}\text { Large } \\
\text { intestine } \\
\text { fluid }\end{array}$ & $\begin{array}{l}\text { Diarrhea } \\
\text { faces }\end{array}$ & \\
\hline Salmonellaanatum & 1 & - & - & 2 & - & - & 2 & 5 \\
\hline Salmonella choleraesuis & 3 & 2 & 1 & 9 & 11 & 9 & 6 & 41 \\
\hline Salmonelladublin & - & 2 & 1 & - & - & - & - & 3 \\
\hline Salmonellaheidelberg & - & - & - & 2 & 1 & 1 & 2 & 6 \\
\hline Salmonella typhimurium & 2 & 1 & 3 & 5 & 8 & 6 & 5 & 30 \\
\hline Salmonellasenftenberg & 1 & - & - & 2 & - & - & 2 & 5 \\
\hline Salmonella weltevreden & 1 & 1 & - & - & - & - & - & 2 \\
\hline Total & 11 & 7 & 6 & 20 & 25 & 20 & 22 & 111 \\
\hline
\end{tabular}




\section{Salmonellosis in Post Weaning Pigs at Swine Farms in Bac Giang Province, Vietnam}

From Table 11 it can be seen that there were 2 strains found positive with serotype Salmonella weltevreden; 3 strains withSalmonella dublin; 5 strains with serotype Salmonellaanatum and Salmonella senftenberg; 6 strains with Salmonella heidelberg; 9 strains with Salmonella enteritidis; the highest number belonged to 2 serotypes of Salmonella typhimurium (30 strains), andSalmonella choleraesuis (41 strains); and for the unknown Salmonella group, there were 10 strains.

Our results were similar to those of Tran TP, et al. on the rate of serotype Salmonella weltevreden determined yet different in the number of serotype Salmonella heidelberg (6/166); similar to the results of Patchanee $\mathrm{P}$, et al. on serotype Salmonella heidelberg, Wendy Wilkins, et al. on the rate of serotype Salmonella typhimurium, Uzzau S, et al. Sylvie Côté, et al. and Steven A. Carlson, et al. on the rates of the serotypes Salmonella dublin, Salmonella choleraesuis, Salmonella enteritidis, Salmonelladublin, Salmonellaanatum, and several unknownSalmonella strains of the serotypes $[19,25,26,27,28,29,32]$.

\section{Determination of the Virulenceof Salmonella Isolates}

PCR reaction was perfomed in order to determine the DNA with theencoded geneproducing virulence factors including Stnenterotoxin, fimA adherence, InvA invasion of 111 Salmonella strain isolatesfrom medical waste ofpost weaning pigswith Salmonellosis. The results are presented in Table 12.

Table 12: Frequency of occurence of the encoded gene producing Stn, fimA, InvA pathogens ofSalmonella Causing Salmonellosisin post weaning pigs

\begin{tabular}{|c|c|c|c|c|c|c|c|}
\hline \multirow{3}{*}{ Serotype Salmonella isolates } & \multirow{3}{*}{$\begin{array}{c}\text { Strains } \\
\text { tested }\end{array}$} & \multicolumn{6}{|c|}{ Frequecy occurance of virulence gene } \\
\hline & & \multicolumn{2}{|c|}{ Stn } & \multicolumn{2}{|l|}{ fimA } & \multicolumn{2}{|c|}{ InvA } \\
\hline & & $\begin{array}{l}\text { Strainsbearing } \\
\text { encoded gene }\end{array}$ & Rate $\%$ & $\begin{array}{l}\text { Strains bearing } \\
\text { encoded gene }\end{array}$ & Rate $\%$ & $\begin{array}{l}\text { Strains bearing } \\
\text { encoded gene }\end{array}$ & Rate \% \\
\hline Salmonellaanatum & 5 & 4 & 80 & 4 & 80 & 2 & 40 \\
\hline Salmonella choleraesuis & 41 & 38 & 92.6 & 38 & 92.6 & 16 & 39 \\
\hline Salmonella enteritidis & 9 & 8 & 88.8 & 8 & 88.8 & 6 & 66.6 \\
\hline Salmonelladublin & 3 & 2 & 66.6 & 1 & 33.3 & 1 & 33.3 \\
\hline Salmonellaheidelberg & 6 & 4 & 66.6 & 4 & 66.6 & 2 & 33.3 \\
\hline Salmonella typhimurium & 30 & 22 & 73.3 & 20 & 66.6 & 8 & 26.6 \\
\hline Salmonella senftenberg & 5 & 4 & 80 & 4 & 80 & 2 & 40 \\
\hline Salmonella weltevreden & 2 & 1 & 50 & 1 & 50 & 1 & 50 \\
\hline Salmonellaunknown & 10 & 8 & 80 & 6 & 60 & 3 & 30 \\
\hline Total & 111 & 91 & 81.9 & 86 & 77.4 & 41 & 36,9 \\
\hline
\end{tabular}

Table 12 shows that the DNA bearingencoded geneStn enterotoxin, fimA adherence, andInvA invasionwere found in all the serotype Salmonellaisolates. The details are as follows:

Stn enterotoxin: Salmonella weltevredenwith the DNA bearing the gene producing Stn accounted for $50.0 \%$; Salmonella dublin and Salmonella heidelberg accounted for $66.6 \%$; Salmonella typhimuriumaccounted for $73.3 \%$; Salmonella senftenberg, Salmonella anatum, Salmonella unknown accounted for 80.0 \%; serotype Salmonella enteritidis accounted for 88.8 $\%$; and serotype Salmonella choleraesuis with the DNA bearing the gene producing Stn accounted for $92.6 \%$.In total, the rate of Salmonella with the encoded gene of Stn enterotoxin accounted for $81.9 \%$ (Figure 1).

Fim A adherence: Salmonelladublinbearing the encoded gene of fim A adherence accounted for the lowest rate of 33.3 $\%$; Salmonella weltevreden accounted for $50.0 \%$; Unknown Salmonella accounted for $60.0 \%$; Salmonella typhimurium and Salmonella Heidelberg accounted for $66.6 \%$; Salmonella senftenbergandSalmonellaanatumaccounted for 80.0 $\%$;Salmonella enteritidisaccounted for $88.8 \%$; and serotype

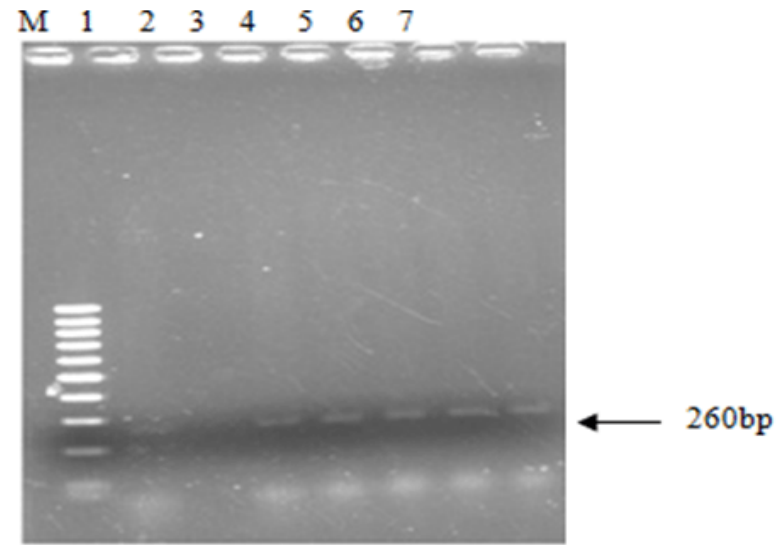

Figure 1: Agarose gel electrophoresis of PCR amplification products using specific Stnenterotoxingene (Stn primers) of Salmonella spp. sisolated. Lane M: $100 \mathrm{bp}$ ladder as molecular DNA marker (M: Marker $100 \mathrm{bp}$, Fermentas, USA), Lane 1: Control positive, Lane 2: Negative Salmonella spp.for Stn production; Lane 3, Lane 4, Lane 5, Lane 6, and Lane 7: Positive Salmonella spp. for Stn production. 


\section{Salmonellosis in Post Weaning Pigs at Swine Farms in Bac Giang Province, Vietnam}

Salmonella choleraesuiscarrying the DNA with the encoded gene of fim A adherence accounted for $92.6 \%$. In total, the rate of the Salmonella strains carrying the encoded gene of fim A adherence accounted for $77.4 \%$

InvA invasion: Salmonella typhimuriumbearing the encoded gene of Inv A invasion accounted for $26.6 \%$; Salmonella unknown accounted for $30.0 \%$; Salmonella heidelberg and Salmonella dublinaccounted for $33.3 \%$; Salmonella choleraesuisaccounted for $39.0 \%$; Salmonella anatum and Salmonella senftenberg accounted for $40.0 \%$;Salmonella weltevredenaccounted for 50.0 $\%$; and serotype Salmonella enteritidis with the DNA bearing the encoded gene of Inv A invasion accounted for $66.6 \%$.

Thus, in comparison with the reports of Chaudhary. J. H,et al. on the ability of producing Stn, fim A, InvA of Salmonella typhimurium and Salmonella enteritidis isolated from pork and slaughterhouses inAhmedabad, Gujarat, our results were similar qualitively yet lower in term of the rate of occurrences of the DNA bearing the encoded gene (our rates are presented above, compated to all the rates of $100 \%$ from Chadhary's report); and our results were also lower than those found by Arunava Das et al., 2012 in a study on the virulence of Salmonella isolated from port, beef, and poultry meat in Tamil Nadu, India (in Arunava Das's report, the rates found were: Stn (100\%), and InvA (100 $\%)$, yet there were similarity in the rate of adherence production (plasmid encoded fimbriae pefA, accounted for $51.42 \%$ ) $[1,2,3]$ (Figure 2).

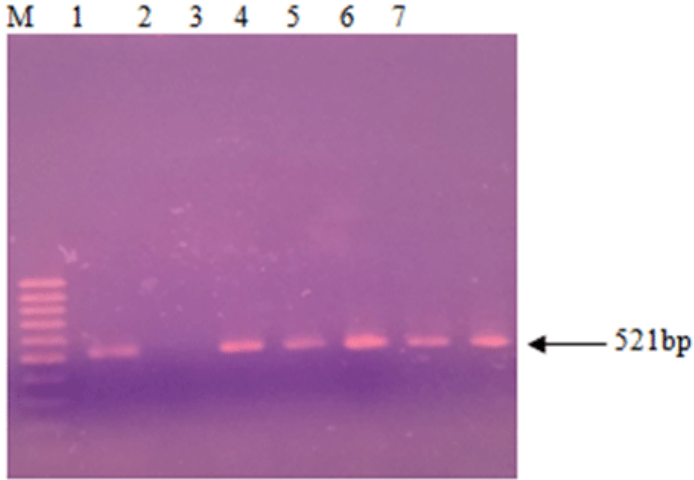

Figure 2: Agarose gel electrophoresis of PCR amplification products using specific Invasion gene (InvA primers) of Salmonella spp. isolated. Lane M: 100 bp ladder as molecular DNA marker (M: Marker 100 bp, Fermentas, USA), Lane 1: Control positive, Lane 2: Negative Salmonella spp.for InvA production; Lane 3, Lane 4, Lane 5, Lane 6, and Lane 7: Positive Salmonella spp. for InvA production.

Table 13 shows that Salmonella isolates from post weaning pigs with Salmonellosis had symptoms of resistance to common antibiotics with different scales by types of antibiotics. The results were similar to those of Quinn P J, et al.; Cheng-Hsun Chiu, et al.; Patchanee P, et al.; Steven A. Carlson, et al. and several other authors $[4,19,21,25]$. The details are as follows:

Serotype Salmonella choleraesuis was found with $1 / 41$ strains resisting to nalidixic acid (2.4\%);3/41 strains resisting to ciprofloxacin, rifampicin, spectinomycin (7.3\%); 4/41 strains

Table 13: Antibiotic resistance of Salmonella isolates

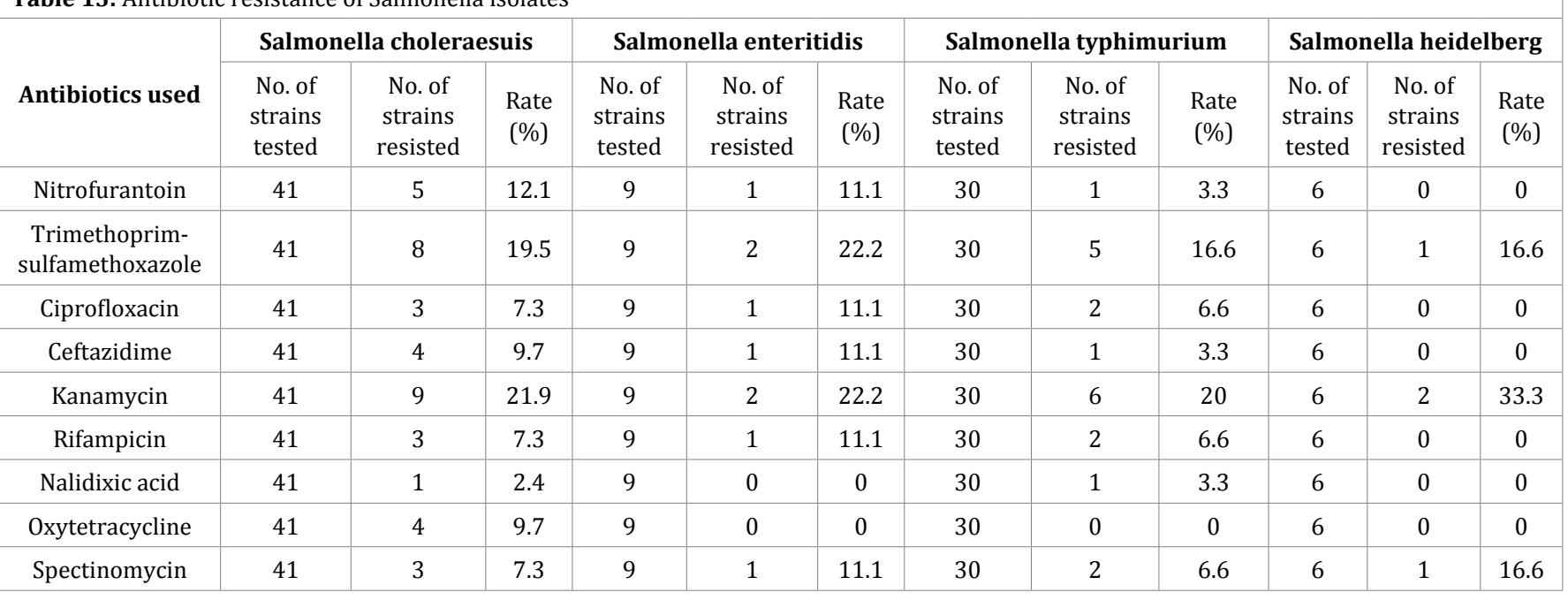

resisting toceftazidime, oxytetracycline (9.7\%); 5/41 strains resisting to nitrofurantoin (12.1\%); 8/41 strains resisting totrimethoprim-sulfamethoxazole (19.5\%); and 9/41 strains resisting to kanamycin (21.9\%).

Serotype Salmonella enteritidis was found with no strains resisting to strains resisting to nalidixic acid and oxytetracycline (0 \%); $1 / 9$ strains resisting to ciprofloxacin, rifampicin, ceftazidime, spectinomycinandnitrofurantoin (11.1\%); 2 and/9 strains resisting to trimethoprim-sulfamethoxazole and kanamycin (22.2\%).

Serotype Salmonella typhimurium was found with no strains resisting to strains resisting to oxytetracycline (0\%); $1 / 30$ strains resisting to nitrofurantoin, nalidixic acid andceftazidime (3.3\%); 2/30 strains resisting to ciprofloxacin, spectinomycin and rifampicin (6.6\%); 5/30 strains resisting totrimethoprimsulfamethoxazole (16.6\%); and6/30 strains resisting to kanamycin $(20.0 \%)$ 


\section{Prevalence and Virulence of Salmonella Bacteria Causing Salmonellosis in Post Weaning Pigs at Swine Farms in Bac Giang Province, Vietnam}

Serotype Salmonella heidelberg was found with no strains resisting to strains resisting to rifampicin, nalidixic acid, oxytetracycline, ceftazidime, ciprofloxacin and nitrofurantoin (0 \%); $2 / 6$ strains resisting to kanamycin (33.3\%); $1 / 6$ strains resisting totrimethoprim-sulfamethoxazole, spectinomycin (16.6 $\%)$.

Thus, our results were similar to those of Li Bai, et al. in a recent study on antibiotic resistance of the serotypes of Salmonella typhimurium, Salmonella derby and Salmonella enteritidis isolated from chicken and pigs in slaughterhouses, with the rate of strains resisting to antibiotics as follows: ciprofloxacin from $8.6 \%$ to $10.0 \%$, cefotaxime from $5.5 \%$ to $8.6 \%$ [13] Similarly, David M Onyango, et al. also revealed that the serotype Salmonella choleraesuis strains isolated from pigs resisted to kanamycin (80.0\%), spectinomycin (31.6\%), sulfamethoxazoletrimethoprim (32.6\%), cephalothin (7.4\%), ofloxacin (24.2\%), and ciprofloxacin and norfloxacin (21.1\%) [6].

\section{Conclusion}

The release of Salmonellain breeder sows occurred in all the studied breeder sow farms in Hiep Hoa district, Bac Giang, Việt Nam (100\%); with the lowest rate of $26.4 \%$, and the highest rate of $43.3 \%$. The average rate of the release of Salmonella from breeder sows to the environment was $34.3 \%$.

The release of Salmonella from breeder sows varied by time and parities:

At the time of two weeks before farrowing, the release of Salmonella was $25.0 \%$ in one-parity sows; $50.0 \%$ in sows in parities $2-5$ and $16.6 \%$ in higher-than-five-parity sows(In total, in breeder sows two weeks before farrowing the release of Salmonella accounted for $32.8 \%$ ).

One week after farrowing (piglets from 7 to 14 days old), the release of Salmonella was $38.4 \%$ in one-parity sows; $51.6 \%$ in sows in parities $2-5$ and $20.0 \%$ in higher-than-five-parity sows(In total, in breeder sows one week after farrowing the release rate of Salmonella was $37.6 \%$ ).

Two weeks after farrowing (pigsfrom14 đến 21 days old), the release of Salmonella was $18.1 \%$ in one-parity sows; 62.0 $\%$ in sows in parities $2-5$ and $22.7 \%$ in higher-than-five-parity sows(In total, in breeder sows two weeks after farrowing the release rate of Salmonella accounted for $40.3 \%$ ).

One week after weaning (pigs from 21 to 28 days old), the release of Salmonella was $14.2 \%$ in one-parity sows; $34.2 \%$ in sows in parities $2-5 ; 23.8 \%$ in higher-than-five-parity sows (In total, breeder sows one week after weaning the release rate of Salmonella was $27.1 \%$ ).

In spring, the release of Salmonella from sows was from $37.5 \%$ to $71.4 \%$; in summer from $33.3 \%$ to57.1 \%; in autumn from $22.5 \%$ to $40.0 \%$; in winter from $0 \%$, and the highest rate of release was $25.0 \%$.

In before weaning piglets, for those without diarrhea, the rate of Salmonella occurred in the faces was from $2.0 \%$ to $3.9 \%$, and the average rate was $1.68 \%$; for those with diarrhea, the rate of Salmonella release found was from $25.0 \%$ to $33.3 \%$, and the average rate was $9.0 \%$.

In post weaning pigs, for the healthy ones, the rate of Salmonella release was from $5.8 \%$ to $13.8 \%$, and the average rate was $10.0 \%$; the rate of Salmonella release found in those with diarrhea was $100 \%$.

In pigs with Salmonellosis, the number of Salmonella release increased from $0.18 \times 109 \mathrm{CFU} /$ Gram of faces to $0.75 \times 109 \mathrm{CFU} /$ Gram of faces, higher than the rate of Salmonella released from healthy pigs (which showed no symptom of the disease), which was only from $0.28 \times 106 \mathrm{CFU} / \mathrm{Gram}$ of faces to $0.93 \times 106 \mathrm{CFU} /$ Gram of faces.

Post weaning pigs found with Salmonellosis accounted for from $5.1 \%$ to $11.1 \%$; and the mortality rate were from $25.0 \%$ to33.3\%.

The rates of Salmonella isolates were $53.3 \%$ (liver samples), $60.0 \%$ (kidney samples), $66.6 \%$ (intestine nodes), $73.3 \%$ (heart blood samples), and in the samples of small intestine fluid, large intestine fluid, and diarrhea faces the rates of Salmonella isolates were $100 \%$. Salmonella isolatesbore the typical biological and chemical characteristics of their genus; $100 \%$ of the strains isolatedgrew well in Rappaport-Vassiliadis environment at $42^{\circ} \mathrm{C}$; were Gram negative stained; $34.9 \%$ had mobility; did not cause hemolysis in blood agar environment; had no lactose fermentation; and $100 \%$ of the tested strains produced $\mathrm{H}_{2} \mathrm{~S}$.

Salmonella isolates were highly virulent on tested mice. At the time of 48 hours after being infected, $85.0 \%$ of the tested mice died of the strains isolated from diarrhea faces; $88.3 \%$ died of the Salmonella strains isolated from large intestine fluid; $93.3 \%$ died of Salmonella strains isolated from small intestine fluid; 97.7 $\%$ died of Salmonella strain isolated from heart blood; and 100\% died Salmonella strain isolated from intestine nodes, kidney, and liver.

Out of the 166 Salmonella bacteria strains isolates, the number of serotypes identified included 2 Salmonella weltevreden, 3 Salmonella Dublin, 5 Salmonella anatumand Salmonella senftenberg, 6 Salmonellaheidelberg, 9 Salmonella enteritidis, 30 Salmonella typhimurium, 41 Salmonella choleraesuis, and 10 unknown Salmonella serotype.

Salmonella weltevredenwhich bore the encoded gene Stn accounted for $50.0 \%$; SalmonelladublinandSalmonella heidelberg accounted for $66.6 \%$; Salmonella typhimuriumaccounted for 73.3 $\%$;Salmonella senftenberg, Salmonella anatum,and Salmonella unknown accounted for $80.0 \%$; Salmonella enteritidisaccounted for $88.8 \%$; Salmonella choleraesuiscarrying the DNA bearing the gene producing Stn accounted for $92.6 \%$. In total, the rate of Salmonella strains carrying the encoded gene Stn enterotoxin accounted for $81.9 \%$. Salmonella Dublin bearing the gene fim A accounted for $33.3 \%$; Salmonella weltevreden accounted for $50.0 \%$; Salmonella unknown accounted for $60.0 \%$; Salmonella typhimurium and salmonella Heidelberg accounted for $66.6 \%$; Salmonella senftenberg and Salmonella anatum accounted for 80.0 


\section{Prevalence and Virulence of Salmonella Bacteria Causing Salmonellosis in Post Weaning Pigs at Swine Farms in Bac Giang Province, Vietnam}

\%; Salmonella enteritidis accounted for $88.8 \%$; and Salmonella choleraesuis accounted for $92.6 \%$. Salmonella typhimurium bearing the gene InvA accounted for $26.6 \%$; Salmonella unknown accounted for $30.0 \%$; Salmonella heidelberg and Salmonella Dublin accounted for $33.3 \%$; Salmonella choleraesuis accounted for $39.0 \%$; Salmonella anatum and Salmonella senftenberg accounted for $40.0 \%$; Salmonella weltevreden accounted for 50.0 $\%$;and Salmonella enteritidis accounted for $66.6 \%$.Out of the 41 strains tested, Salmonella choleraesuis had 1 strain resisting to nalidixicacid (2.4\%); 3strains resisting to ciprofloxacin, rifampicin, and spectinomycin (7. $3 \%$ ); 4strains resisting toceftazidime and oxytetracycline (9.7\%); 5strains resisting to nitrofurantoin (12.1\%); 8strains resisting totrimethoprimsulfamethoxazole (19.5\%); and9strains resisting to kanamycin (21.9\%).

Out of the 9 strains tested, Salmonella enteritidis was found with no strains resisting to nalidixic acid and oxytetracycline; 1 strain resisting to ciprofloxacin, rifampicin, ceftazidime, spectinomycinandnitrofurantoin (11.1\%); and 2 strains resisting totrimethoprim-sulfamethoxazole and kanamycin (22.2\%).

Out of the 30 strains tested, serotype Salmonella typhimurium was found with no strains resisting to oxytetracycline; 1strain is resisting to nitrofurantoin, nalidixic acid and ceftazidime (3.3\%); 2strains resisting to ciprofloxacin, spectinomycin and rifampicin (6.6\%); 5strains resisting totrimethoprim-sulfamethoxazole (16.6\%); and6strains resisting to kanamycin (20.0\%).

\section{Acknowledgement}

The authors are grateful to the Department of Microbiology, Institute of Life Sciences and Thái Nguyen University of Agriculture and Forestry, Institute of Genome Research, Vietnam Academy of Science and Technologyfor providing materials support to the present investigation.

\section{Reference}

1. Arunava Das, Sree Hari S, Shalini U, Ganeshkumar A, Karthikeyan M. Molecular Screening of Virulence Genes from Salmonella enterica Isolated from Commercial Food Stuffs. BIOSCIENCES BIOTECHNOLOGY RESEARCH ASIA. June 2012; 9(1):363-369.

2. Bacterial serotyping guide for Salmonella

3. Chaudhary JH, Nayak JB, Brahmbhatt MN, Makwana PP. Virulence genes detection of Salmonella serovars isolated from pork and slaughterhouse environment in Ahmedabad, Gujarat. Vet World. 2015;8(1):121-124. doi: 10.14202/vetworld.2015.121-124.

4. Cheng-Hsun Chiu, Lin-Hui Su, Chishih Chu. Salmonella enterica Serotype Choleraesuis: Epidemiology, Pathogenesis, Clinical Disease, and Treatment. Clin Microbiol Rev. 2004;17(2):311-322. doi: 10.1128/CMR.17.2.311-322.2004

5. Chiara F. Magistrali, Nicoletta D'Avino, Francesca Ciuti, Lucilla Cucco, Carmen Maresca, Marta Paniccià, et al. Longitudinal study of fecal Salmonella shedding by sows. Journal of Swine Health and Production. November and December. 2011;19(6):326-330.
6. David M Onyango, Violet M Ndeda, Sarah A Wandili, Sifuna A Wawire, Philip Ochieng. Antimicrobial profile of Salmonella enterica serotype Choleraesuis from free-range swine in Kakamega fish market, western Kenya. J Infect Dev Ctries. 2014; 8(11):1381-1390.

7. Evangelopoulou G, Kritas S, Christodoulopoulos G,Burriel A R. The commercial impact of pig Salmonella spp. infections in border-free markets during an economic recession. Vet World. 2015;8(3):257272.

8. Gieraltowski L, Higa J, Peralta V, Green A, Schwensohn C, Rosen H, et al. Defibagy of emergent multidrug-resistant Salmonella enterica serotype Typhimurium strains carrying the virulence resistance plasmid pUO-StVR2. Journal of Antimicrobial Chemotherapy .2006: $57 ; 39-45$

9. Ibrahim G, Fleet G H.Review: Detection of Salmonellae using accelerated methods.Int. J. Food Microbiol.1985;2(5):259 272.

10. Jerome C. Nietfeld, Ingrid Feder, Ted T. Kramer, David Schoneweis, M. M. Chengappa. Preventing Salmonella infection in pigs with offsite weaning. Swine Health and Production. 1998;6(1):27-32.

11. John M. Fairbrother, Carlton L. Gyles. Colibacillosis. Diseases of swine.10th Edition.Wiley-Blackwell. A John Wiley \& Sons, Inc., Publication. 2012

12. Kumar K, Saklaini A.C, Singh S, Singh V.P., 2008. Evaluation of specificity for inv A gene PCR for detection of Salmonella spp. [November 07-09-2008];Proceeding of VIIth Annual Conference of Indian Association of Veterinary Public Health Specialists (IAVPHS). 2008.

13. Li Bai, Ruiting Lan ,Xiuli Zhang ,Shenghui Cui,Jin Xu,Yunchang Guo, et al. Prevalence of Salmonella Isolates from Chicken and Pig Slaughterhouses and Emergence of Ciprofloxacin and Cefotaxime Co-Resistant S. enterica Serovar Indiana in Henan, China. Plos One. 2015.

14. Lo Fo Wong, Hald T, van der Wolf PJ, Swanenburg M. Epidemiology and control measures for Salmonella in pigs and pork. Livestock Production Science. 2002;76(3):215-222.

15. Makino S, Kurazono H, Chongsanguam M, Hayashi H, Cheun H, Suzuki S, et al. Establishment of the PCR system specific to Salmonella spp. and its application for the inspection of food and fecal samples. J. Vet. Med. Sci. 1999;61(11):1245-1247.

16. Naravaneni R, Jamil K. Rapid detection of food-borne pathogens by using molecular techniques. J. Med. Microbiol. 2005;54:51-54.

17. Nicole C Burdick Sanchez, Paul R Broadway, Jeffery A Carroll, Elena V Gart, Laura K. Bryan, Sara D. Lawhon. Weaned pigs experimentally infected with Salmonella display sexually dimorphic innate immune responses without affecting pathogen colonization patterns. Livestock Issues Research Unit, USDA-ARS, Lubbock, TX 79403 and Department of Veterinary Pathology, College of Veterinary Medicine 
and Biomedical Sciences, Texas A\&M University, College Station 77843.2017

18. Oxoid Salmonella Test Kit. DR1108 .

19. Patchanee P, Zewde B M, Tadesse D A, Hoet A, Gebreyes W A Characterization of multi-drug resistant Salmonella enterica serovar Heidelberg isolated from humans and animals. Foodborne Pathog. Dis. 2008; 5(6): 839-851

20. Pires AF, Funk JA, Bolin CA. Longitudinal study of Salmonella shedding in naturally infected finishing pigs. Epidemiol Infect. 2013;141(9):1928-1936. doi: 10.1017/S0950268812002464

21. Quinn P J, Carter M E, Markey B K, Carter G R. Clinical Veterinary Microbiology. Wolfe publishing. Mosby-Year Book Europe Limited .2002; $199-202$

22. Renata Ivanek, Julia Osterberg, Raju Gautam, Susanna Sternberg Lewerin. Fecal Shedding and Immune Responses are Dose and Serotype. Dependent in Pigs. Published. 2012.

23. Shua J Chai, Patricia L White, Sarah L Lathrop, Suzanne M Solghan, Carlota Medus, Beth M McGlinchey et al. Salmonella enterica Serotype Enteritidis: Increasing Incidence of Domestically Acquired Infections. Clin Infect Dis. 54;suppl 5:488-S497. 2012.

24. Sperber W, Deibel RH. Accelerated procedure for Salmonella detection in dried foods and feeds involving only broth cultures and serological reactions. Applied Microbiol. 1969; 17: 533- 539

25. Steven A Carlson, Alison E Barnhill, Ronald W Griffith. Salmonellosis Diseases of swine.10th Edition.Wiley-Blackwell. A John Wiley \& Sons, Inc., Publication. 2012.

26. Sylvie Côté, Ann Letellier, Louise Lessard, Sylvain Quessy, Distribution of Salmonella in tissues following natural and experimental infection in pigs. Can J Vet Res. 2004;68(4):241-248.
27. Tran TP, Ly TL, Nguyen TT, Akiba M, Ogasawara N, Shinoda D, et al. Prevalence of Salmonella spp. in pigs, chickens and ducks in the Mekong Delta, Vietnam. J Vet Med Sci. 2004;66(8):1011-1014.

28. Uzzau S, Brown DJ, Wallis T, Rubino S, Leori G, Bernard S, et al. Host adapted serotypes of Salmonella enteric. Epidemiol. Infect. 2001;125(2):229-255.

29. Vassiliadis P. The Rappaport Vassiliadis (RV) enrichment medium for the isolation of Salmonellas: an overview. J. Appl Bacteriol 1983;54(1):69-76. doi: 10.1111/j.1365-2672.1983.tb01302.x

30. Wallace H Andrews, Hua Wang, Andrew Jacobson, Thomas Hammack. Bacteriological Analytical Manual (BAM). Chapter 5. Salmonella. 2016

31. Walsh M C, Rostagno M H, Gardiner G E , Sutton A L, Richert B $\mathrm{T}$, Radcliffe J S. Controlling Salmonella infection in weanling pigs through water delivery of direct-fed microbials or orliveric acids. Part I: Effects on growth performance, microbial populations, and immune status. Journal of Animal Science. 2010; 90(1):261-271. doi:10.2527/jas.2010-3598

32. Wendy Wilkins, Andrijana Rajić, Cheryl Waldner, Margaret Mc Fall, Eva Chow, Anne Muckle, Leigh Rosengren. Distribution of Salmonella serovars in breeding, nursery, and grow-to-finish pigs, and risk factors for shedding in ten farrow-to-finish swine farms in Alberta and Saskatchewan. Can J Vet Res. 2010;74(2): 81-90.

33. Xin-peng Li, Ri-hong Gao, Pei-bin Hou,Yan-yan Ren, Hua-ning Zhang,Kui-ying Jiang, et al. Characterization of the Salmonella enterica Serotype Isangi Isolated from Patients for the First Time in China. Foodborne Pathogens and Disease. 2017;14(8):427-431. 